\title{
PEMBUATAN SURAT KUASA \\ MEMBEBANKAN HAK TANGGUNGAN \\ TANPA DIIKUTI AKTA PEMBERIAN HAK TANGGUNGAN
}

\author{
Sri Endah Cahayani \\ Magister Kenotariatan \\ Program Pascasarjana Universitas Islam Malang \\ Jl. Mayjen Haryono No.193 Malang \\ Email : endah9109@gmail.com
}

\begin{abstract}
Abstrak
Jaminan yang diberikan oleh debitor kepada bank masih relatif cukup banyak dengan bukti kepemilikan yang masih berupa letter C, sehingga dalam pengikatan jaminannya dengan menggunakan Surat Kuasa Membebankan Hak Tanggungan (SKMHT) dengan jangka waktu 3 (tiga) bulan, dengan demikian memerlukan perpanjangan beberapa kali untuk dapat dilakukan pemasangan Hak Tanggungan, karena untuk proses pengurusan letter $\mathrm{C}$ menjadi sertifikat dibutuhkan waktu relatif cukup panjang kurang lebih 12 (duabelas) bulan, hal ini tidak menutup kemungkinan tidak dapat terlaksananya penandatanganan perpanjangan Surat Kuasa Membebankan Hak Tanggungan (SKMHT).
\end{abstract}

Kata kunci: jaminan, akta, hak tanggungan, surat kuasa

\section{Abstract}

The guarantee given by the debtor to the bank is still relatively large with proof of ownership that is still in the form of letter $C$, so that in binding the guarantee by using a Power of Attorney Charges (SKMHT) with a period of 3 (three) months, thus requiring several extensions to mortgage rights can be done, because for the process of arranging the letter $C$ into a certificate, it takes relatively long time of approximately 12 (twelve) months, this does not rule out the possibility of signing the extension of the Power of Attorney Charges (SKMHT).

Keywords: guarantee, deed, mortgage rights, power of attorney

\section{PENDAHULUAN}

Lembaga perbankan merupakan perantara keuangan dari dua pihak, yaitu pihak yang kelebihan dana dan pihak yang kekurangan dana. Hal tersebut tercermin pada Pasal 1 ayat (2) Undang-Undang Republik Indonesia Nomor 10 Tahun 1998 tentang perubahan atas Undang-Undang Nomor 7 Tahun 1992 tentang Perbankan, yang dimaksud Bank adalah badan usaha yang menghimpun dana dari masyarakat dalam bentuk simpanan dan 
menyalurkannya kepada masyarakat dalam bentuk kredit atau bentuk-bentuk lainnya dalam rangka meningkatkan taraf hidup rakyat banyak. Jadi pada intinya bahwa perbankan merupakan badan usaha yang menghimpun dana dari masyarakat dan menyalurkannya kembali kepada masyarakat.

Lembaga perbankan di Indonesia memiliki misi dan fungsi sebagai agen pembangunan (agen of development), yaitu sebagai lembaga yang bertujuan menunjang pelaksanaan pembangunan nasional dalam rangka meningkatkan pemerataan, pertumbuhan ekonomi dan stabilitas nasional ke arah peningkatan kesejahteraan rakyat banyak.

Dalam rangka untuk mewujudkan misi dan fungsi tersebut Lembaga Perbankan diharapkan berperan aktif dalam menunjang kegiatan pembangunan nasional. Peran tersebut diwujudkan dalam fungsi utamanya sebagai lembaga intermediasi atau institusi perantara antara debitor dan kreditor. Dengan demikian pelaku ekonomi yang membutuhkan dana untuk menunjang kegiatannya dapat terpenuhi dan kemudian roda perekonomian bergerak.

Seiring berjalannya waktu semakin banyak bermunculan lembaga perbankan, kondisi yang sedemikian membuat semakin banyaknya persaingan diantara lembaga perbankan itu sendiri dan akibatnya banyak kelonggaran yang dilakukan oleh lembaga perbakan dalam melakukan memberian kredit kepada debitur. Hal ini dilakukan untuk mendapatkan debitor sebanyak mungkin agar target perusahaan dapat tercapai.

Dalam pemberian kredit bank wajib mempunyai atau memiliki keyakinan terhadap debitur, bahwa untuk memperoleh keyakinan tersebut, maka pihak bank sebelum memberikan kredit harus melakukan penilaian yang seksama, yaitu yang lazim dikenal dengan Formula the five $C$ 's of credit analysis atau prinsip $5 \mathrm{C}$ 's, yang terdiri dari: charakter (penilaian watak), capacity (penilaian kemampuan), capital (penilaian terhadap modal), collateral (penilaian terhadap agunan/jaminan), condition of economie (penilaian terhadap prospek usaha debitur) ${ }^{1}$.

Berlandaskan dari keyakinan kreditur terhadap debitor dalam pemberian fasilitas kredit yang berdasar pada formula the five C's of credit analysis atau prinsip $5 \mathrm{C}$ 's tersebut, yang salah satunya yaitu: collateral (penilaian terhadap agunan/jaminan), dimana dengan adanya agunan atau jaminan, hal ini dimaksudkan sebagai solusi hukum untuk memberikan kepastian pengembalian pinjaman tersebut. Dalam praktek jaminan yang sering digunakan adalah jaminan kebendaan, yang salah satunya yaitu berupa tanah yang pengikatan jaminannya melalui lembaga jaminan hak tangungan.

${ }^{1}$ Uswatun Hasanah, Hukum Perbankan, (Malang: Setara Press, 2017), hal. 72 
Hak tanggungan merupakan lembaga hak jaminan atas tanah yang kuat dan mampu memberikan kepastian hukum bagi para pihak, yang memberikan kedudukan yang lebih tinggi bagi kreditor pemegang hak tanggungan dibandingkan dengan kreditur lainnya. Hak tanggungan merupakan perjanjian ikutan (accessoir) terhadap perjanjian pokok, sehingga dalam pelaksanaannya, pemberian hak tanggungan hanya dapat dilaksanakan apabila dibuat dalam bentuk perjanjian, hal ini sesuai dengan Pasal 10 ayat (1) dari Undang-Undang Nomor 4 Tahun 1996 tentang Hak Tanggungan, yaitu pemberian haktanggungan didahului dengan janji untuk memberikan hak tanggungan sebagai jaminan pelunasan utang tertentu, yang dituangkan di dalam dan merupakan bagian tak terpisahkan dari perjanjian utang-piutang yang bersangkutan atau perjanjian lainnya yang menimbulkan utang tersebut.

Pada dasarnya pemberian hak tanggungan wajib dilakukan oleh pemilik sendiri, hal ini sesuai dengan asas umum yang berlaku bahwa pada dasarnya tindakan hukum harus dilakukan oleh yang berkepentingan sendiri. Namun tidak berarti hal tersebut tidak dapat disimpangi apabila suatu keadaan yang menghendakinya. Suatu keadaan yang menghendaki bisa dilakukan dikarenakan peraturan memperbolehkan.

Undang-Undang Nomor 4 Tahun 1996 tentang Hak Tanggungan bertujuan memberikan landasan untuk dapat berlakunya lembaga hak tanggungan yang kuat, diantaranya mengenai kedudukan SKMHT, sebagaimana yang disebutkan dalam Pasal 15 Undang-Undang Nomor 4 Tahun 1996 memberikan kesempatan kepada pemberi hak tanggungan untuk menggunakan SKMHT.

Di dalam Pasal 15 ayat (1) Undang-Undang Nomor 4 Tahun 1996 tentang Hak Tanggungan atas tanah beserta benda-benda yang berkaitan dengan tanah menyebutkan SKMHT wajib dibuat dengan akta notaris atau akta Pejabat Pembuat Akta tanah (PPAT) dan memenuhi persyaratan sebagai berikut :

1. Tidak memuat kuasa untuk melakukan perbuatan hukum lain daripada membebankan hak tanggungan.

2. Tidak memuat kuasa subtitusi.

3. Mencantumkan secara jelas objek hak tanggungan, jumlah utang dan nama serta identitas krediturnya, nama dan identitas debitur apabila debitur bukan pemberi hak tanggungan. ${ }^{2}$

Dari persyaratan yang diharuskan untuk pembuatan SKMHT sebagaimana disebutkan dalam Pasal 15 ayat (1) Undang-Undang Nomor 4

${ }^{2}$ Hadi Setia Tunggal., Undang-Undang Hak Atas Tanah Beserta Benda-Benda Yang Berkaitan Dengan Tanah Dan Perturan Pelaksanaanya, (Jakarta: Harvarindo,2005), hal. 9. 
Tahun 1996 tersebut diatas, dapat diketahui bahwa pembuatan SKMHT harus dibuat dalam suatu kuasa khusus. Kuasa khusus yang dimaksud adalah:

a. Apabila pemberi hak tanggungan tidak dapat hadir sendiri di hadapan Pejabat Pembuat Akta Tanah (PPAT).

b. SKMHT harus dalam bentuk akta autentik yang dibuat oleh Notaris atau Pejabat Pembuat Akta Tanah (PPAT).

c. Substansi SKMHT dibatasi, yaitu hanya memuat perbuatan hukum membebankan hak tanggungan,tidak memuat kuasa untuk menjual, menyewakan objek hak tanggungan, tidak memuat hak untuk menggantikan penerima kuasa melalui pengalihan, mencantumkan secara jelas objek hak tanggungan, jumlah utang debitor dan nama serta identitas kreditornya, nama dan identitas debitor apabila debitor bukan pemberi hak tanggungan jika tidak dipenuhinya syarat tersebut diatas, surat kuasa yang bersangkutan batal demi hukum.

Pengertian "batal demi hukum" dalam hal ini adalah bahwa SKMHT yang bersangkutan tidak dapat dipergunakan sebagai dasar pembuatan APHT. Pejabat Pembuat Akta Tanah (PPAT) wajib menolak membuat Akta Pemberian Hak Tanggungan (APHT), apabila SKMHT tidak dibuat sendiri oleh pemberi hak tanggungan atau tidak memenuhi persyaratan tersebut atas.

Untuk mencegak berlarut-larutnya pemberian kuasa dan demi tercapainya kepastian hukum, KMHT dibatasi jangka waktunya. Didalam Pasal 15 ayat (3) Undang-Undang Nomor 4 Tahun 1996 menentukan bahwa terhadap tanah yang sudah terdaftar, SKMHT wajib segera diikuti dengan pembuatan APHT dalam jangka waktu 1 (satu) bulan sesudah diberikan.

Sedangkan untuk Pasal 15 ayat (4) Undang-Undang Nomor 4 Tahun 1996 menentukan bahwa terhadap tanah yang belum terdaftar, SKMHT wajib segera diikuti dengan pembuatan APHT dalam jangka waktu 3 (tiga) bulan sesudah diberikan.

Untuk kredit tertentu ini telah diatur dalam Peraturan Menteri Agraria dan Tata Ruang/Kepala Badan Pertanahan Nasional Republik Indonesia Nomor 22 Tahun 2017 tentang Penetapan Batas Waktu Penggunaan Surat Kuasa Membebankan Hak Tanggungan Untuk Menjamin Pelunasan Kredit Tertentu. Peraturan tersebut sebagai pengganti dari Peraturan Menteri Negara Agraria/ Kepala Badan Pertanahan Nasional Nomor 4 Tahun 1996.

Dalam Peraturan Menteri Agraria dan Tata Ruang/Kepala Badan Pertanahan Nasional Republik Indonesia Nomor 22 Tahun 2017 Pasal 2 disebutkan bahwa SKMHT untuk menjamin pelunasan 
Kredit/Pembiayaan/Pinjaman berlaku sampai dengan berakhirnya perjanjian pokok yaitu :

a. Kredit/pembiayaan/pinjaman yang diberikan kepada nasabah Usaha mikro dan usaha kecil, dalam lingkup pengertian usaha produktif milik perorangan dan/atau badan usaha perorangan.

b. Kredit/pembiayaan/pinjaman yang ditujukan untuk pengadaan perumahan yaitu: 1) kepemilikan atau perbaikan rumah inti, rumah sederhana atau rumah susun dengan luas tanah maksimum $200 \mathrm{~m} 2$ (dua ratus meter persegi) dan luas bangunan tidak lebih dari $70 \mathrm{~m} 2$ (tujuh puluh meter persegi); dan 2) kepemilikan atau perbaikan Kapling Siap Bangun (KSB) dengan luas $54 \mathrm{~m} 2$ (lima puluh empat meter persegi) sampai dengan $72 \mathrm{~m} 2$ (tujuh puluh dua meter persegi) dan kredit yang diberkan untuk membiayai bangunannya.

c. Kredit/ pembiayaan/pinjaman produktif lainnya dengan plafon sampai dengan Rp. 200.000.000,- (dua ratus juta rupiah).

Sedangakan dalam Pasal 3 Peraturan MenteriAgraria dan Tata Ruang / Kepala Badan Pertanahan Nasional Republik Indonesia Nomor 22 Tahun 2017 menyebutkan bahwa SKMHT yang berlaku sampai 3 (tiga) bulan, terhadap hak atas tanah yang sertifikatnya sedang dalam masa pengurusan

Adanya pembedaan batas waktu berlakunya SKMHT tersebut, tentu juga akan membawa konsekuensi hukum bagi penerima SKMHT (dalam hal ini kreditor), jika SKMHT tersebut tidak ditindaklanjuti dengan pembuatan APHT, berikut pendaftaran hak tanggungan pada Kantor Badan Pertanahan (BPN) untuk diterbitkan Sertifikat Hak Tanggungan (SHT), maka jika terjadi kredit macet, kreditur tidak mempunyai hak preferen.

Begitu juga jika batas waktu SKMHT tersebut sudah habis masa berlakunya sebagaimana yang dimaksudkan dalam Pasal 15 ayat (3) atau Pasal 15 ayat (4) atau waktu yang ditentukan menurut ketentuan sebagaimana yang dimaksud dalam Pasal 15 ayat (5) Undang-Undang Nomor 4 Tahun 1996 dan tidak ditindaklanjuti dengan pembuatan APHT, berikut pendaftaran hak tanggungan pada BPN untuk diterbitkan Sertifikat Hak Tanggungan (SHT), maka batal demi hukum.

\section{METODE PENELITIAN}

Jenis Penelitian yang digunakan dalam penelitian ini adalah penelitian hukum empiris (yuridis empiris), yaitu penelitian hukum yang berfungsi untuk melihat hukum dalam arti nyata dan meneliti bagaimana bekerjanya hukum di lingkungan masyarakat.

Pendekatan yang digunakan dalam penulisan penelitian ini yaitu pendekatan perundang-undangan (statute approach) dan pendekatan 
kualitatif dalam penelitian hukum empiris. Lokasi penelitian dilakukan di PT. Bank Panin Tbk.Kantor Cabang Blitar. Populasi dan pengambilan sample dilakukan dengan mengambil sebagian dari populasi yang dianggap dapat mewakili populasi.

Sumber bahan hukum yang digunakan dalam penelitian ini adalah jenis data primer dan sekunder. Sumber data primer diperolah langsung dari sumbernya, baik melalui wawancara, maupun observasi, sedangkan data sekunder yaitu data yang diambil dari bahan kepustakaan yang terdiri dari 3 (tiga) sumber bahan hukum yaitu: bahan hukum primer, bahan hukum sekunder dan bahan hukum tersier.

Teknik pengumpulan data dilakukan dengan wawancara, observasi dan survei lapangan, serta studi peraturan perundang-undangan. Dalam penelitian ini penulis menggunakan teknik analisis kualitatif, karena data yang diolah hanya berupa uraian kalimat baik dari hasil wawancara maupun dari pengkajian literatus yang ada. Dari data yang telah dianalisis tersebut memperoleh data yang deskriptif yang mengungkapkan hasil penelitian apa adanya tentang permasalahan yang telah dirumuskan.

\section{PEMBAHASAN}

\section{Akibat hukum bagi kreditur}

Pada asasnya pemberian hak tanggungan wajib dihadiri dan dilakukan sendiri oleh pemberi hak tanggungan sebagai pihak yang berwenang melakukan perbuatan hukum membebankan hak tanggunganatas obyek yang dijadikan jaminan. Namun apabila pemberi hak tanggungan tersebut berhalangan hadir dikarenakan sesuatu hal, untuk memberikan hak tanggungan dan menandatangani APHT dapat dikuasakan kepada pihak lain, yang dalam hal ini pemberi hak tangungan dapat memberikan kuasa kepada pihak yang ditunjuk untuk menjalankan SKMHT ada 2 (dua) alasan yaitu alasan subjektif dan alasan objektif. ${ }^{3}$ Apabila pemberi hak tanggungan tidak bisa hadir/berhalangan hadir, maka pemberi hak tanggungan dapat menunjuk pemegang hak tanggungan atau pihak lain sebagai kuasanya untuk mewakilinya dalam pemberian tanggungan. Pemberian kuasa membebankan hak tanggungan tersebut dituangkan dalam SKMHT.

SKMHT merupakan surat kuasa khusus ditujukan kepada Pemegang Hak Tanggungan atau pihak lain untuk mewakili diri Pemberi Hak Tanggungan hadir di hadapan Notaris/PPAT untuk melakukan pembebanan Hak Tanggungan, berhubung Pemberi Hak Tanggungan tidak

\footnotetext{
${ }^{3}$ Boedi Harsono, Hukum Agraria Indonesia Jilit I, (Jakarta: Djembatan, 1999), hal
} 
datang menghadap sendiri untuk melakukan tindakan membebankan Hak Tanggungan di hadapan Notaris/PPAT ${ }^{4}$

Sebelum berlakunya Undang-Undang Hak Tanggungan, penggunaan SKMHT seringkali dipergunakan untuk menunda pembebanan hak tanggungan atas jaminan kredit. Banyak kreditor yang memegang SKMHT yang hanya akan dilaksanakannya apabila ada gejala debitor akan cederá janji. Walaupun resiko akibat belum dibebankannya hak tanggungan itu ditanggung sepenuhnya oleh kreditor (pemegang jaminan).

Pembuatan SKMHT dilatarbelakangi berbagai kepentingan dan hambatan, terutama karena proses pembebanan, pemberian, dan pemasangan Hak Tanggungan tidak mudah antara lain disebabkan hal-hal sebagai berikut: ${ }^{5}$

- Harus melalui suatu formalitas tertentu

- Memakan waktu yang lama relatif cukup lama

- Memerlukan biaya pembebanan yang relatif cukup tinggi

- Kredit yang diberikan oleh kreditor kepada debitor jangka waktunya pada dasaraya terlalu singkat dan jumlahnya juga tidak terlalu besar

- Benda yang akan dijaminkan belum bersertifikat

- Kreditor mempercayai debitor, artinya ia merasa terjamin bilamana telah mendapat kuasa dari debitor untuk memasang Hak Tanggungan. Sebaliknya, debitor juga merasa tertolong dan aman dengan dipasangnya hak tanggungan oleh pihak kreditor.

- Pemberi hak tanggungan terkadang tidak dapat hadir sendiri di hadapan Notaris/PPAT untuk membuat APHT.

Pada pasal 15 ayat 1 Undang-Undang Nomor 4 Tahun 1996 antara lain menyatakan, SKMHT wajib dibuat dengan akta Notaris atau akta PPAT dan memenuhi persyaratan.

Dalam pemberian hak tanggungan dimana pada tahap awal dimulai dengan proses perjanjian kredit, baik secara notariel maupun di bawah tangan, sebagai penjanjian pokok antara debitor dengan bank, kemudian dilanjutkan dengan penandatangan APHT sebagai perjanjian accesoir atau ikutan, namun karena satu dan lain hal pemberian hak tanggungan tidak dapat dilakukan bersamaan dengan penandatangan perjanjian kredit, dalam hal yang demikian yang harus dilakukan pada saat penandatangan perjanjian kredit, diikuti dengan penandatangan SKMHT antara pemberi kuasa yaitu debitor atau penjamin dengan penerima kuasa yaitu bank. Dan tidak menutup kemungkinan bahwa penandatanganan SKMHT dilakukan beberapa kali untuk dapat dilakukan penandatanganan APHT.

\footnotetext{
${ }^{4}$ Supriadi, Hukum Agraria, (Jakarta: Sinar Grafika, 2012), hal 186.

${ }^{5}$ Rachmadi Usman, Hukum Kebendaan, (Jakarta: Sinar Grafika, 2013), hal 347.
} 
Setelah semua persyaratan untuk dapat dilakukan penandatangan APHT dapat dipenuhi, maka pemberi hak tanggungan yaitu debitor atau penjamin harus menandatangi APHT, atau berdasarkan SKMHT yang telah ditandanganai tersebut bank dapat melakukan penandatanganan APHT, baik yang bertindak untuk dan atas nama pemberi hak tanggungan maupun bertindak untuk dan atas nama penerima hak tanggungan. Untuk selanjutnya dilakukan proses pendaftaran Hak Tanggungan pada BPN Kabupaten/Kota setempat untuk diterbitkan Sertifikat Hak Tanggungan (SHT).

Dalam Pasal 15 ayat (3) Undang-Undang Nomor 4 Tahun 1996, jangka waktu yang diberikan untuk SKMHT 1 (satu) bulan setelah dilakukan penandatangan SKMHT, untuk tanah yang telah terdaftar. Sedangkan dalam Pasal 15 ayat (4), jangka waktu yang diberikan untuk SKMHT 3 (tiga) bulan setelah dilakukan penandatangan SKMHT, untuk tanah yang telah belum terdaftar.

Pengertian tanah terdaftar ialah tanah tersebut telah bersertifikat atau tanah tersebut sudah memiliki sertifikat dan terdafar di Kantor Badan Pertanahan Nasional (BPN) tertulis atas nama pemberi hak tanggungan tersebut. Sedangkan untuk tanah yang belum terdaftar ialah tanah tersebut secara administrasi belum terdaftar atas nama Pemberi Hak Tanggungan atau bisa juga tanah tersebut sedang dilakukan proses balik nama, pemecahan, pemisahan, ataupun pendafataran pertama kali di BPN Kabupaten / Kota Setempat.

Jadi setelah dibuat dan ditandatangani SKMHT tersebut maka Notaris/PPAT membuat APHT. APHT ialah akta autentik yang khusus berisi tentang pemberian hak tanggungan kepada kreditor tertentu sebagai jaminan untuk pelunasan piutangnya. Setelah dibuat dan ditandatangani APHT tersebut maka APHT wajib didaftarkan BPN selambat-lambatnya 7 (tujuh) hari kerja setelah penandatangan APHT tersebut menyerahkan kepada Kantor BPN dengan berkas yang diperlukan untuk Pendaftaran.

Setelah APHT didaftarkan di Kantor BPN, Kantor BPN Kabupaten/Kota Setempat menerbitkan sertifikan hak tanggungan sebagai dasar jaminan terhadap pihak bank.

Apabila setelah proses pembuatan dan penandatanganan Perjanjian Kredit dan kemudian pembuatan dan penandatanganan SKMHT, yang tidak dilakukan proses selanjutnya yaitu pembuatan dan penandatanganan APHT serta pendaftaran hak tanggungan, dengan sendirinya kreditor tersebut tidak memiliki hak preferent, yaitu yang memberikan kedudukan yang diutamakan kepada Kreditor tertentu terhadap kreditor-kreditor lain. Sebagaimana diatur dalam Pasal 1 ayat (1) Undang-Undang Nomor 4 Tahun 1996 bahwa hak tanggunngan atas tanah berserta benda-benda yang terkait dengan tanah, yang selanjutnya disebut hak tanggungan, adalah hak 
jaminan yang dibedakan pada hak atas tanah sebagaimana dimaksud dalam Undang-Undang Nomor 5 Tahun 1960, berikut atau tidak berikut bendabenda lain yang merupakan satu kesatuan dengan tanah itu, untuk pelunasan utang tertentu, yang memberikan kedudukan yang diutamakan kepada kreditor tertentu terhadap kreditor-kreditor lain.

Sedangkan fasilitas kredit yang diberikan PT. Bank Panin Tbk. kepada debitur disamping plafon kredit di atas Rp. 50.000.000,- (lima puluh juta rupiah) juga memberikan kredit dengan plafon di bawah Rp. 50.000.000,- (lima puuh juta rupiah), sehingga tidak menutup kemungkinan bahwa fasilitas kredit tersebut untuk pengikatan jaminannya hanya melalui penandatangan SKMHT dan jangka waktu yang diberikan untuk SKMHT sampai berakhirnya perjanjian pokok, sebagai mana yang diatur dalam pasal 2 Peraturan Menteri Agraria dan Tata Ruang / Kepala Badan Pertanahan Nasional Republik Indonesia Nomor 22 Tahun 2017, tentang Penetapan Batas Waktu Penggunaan SKMHT. Untuk Menjamin pelunasan kredit tertentu, peraturan tersebut sebagai pengganti dari Peraturan Menteri Negara Agraria/Kepala Badan Pertanahan Nasional Nomor 4 Tahun 1996, tentang Penetapan Batas Waktu Penggunaan SKMHT. Untuk Menjamin Pelunasan Kredit Tertentu,begitu pula dalam Pasal 15 ayat (5) Undang- Undang Nomor 4 Tahun 1996 disebutkan bahwa ketentuan sebagaimana pada ayat (3) dan ayat (4) tidak berlaku dalam hal surat kuasa membebankan hak tanggungan diberikan untuk menjamin kredit tertentu yang ditetapkan dalam peraturan perundang-undangan yang berlaku.

Begitu pula dengan jaminan yang diserahkan debitor kepada PT. Bank Panin Tbk. yang bukti kepemilikannya masih berupa Letter C, sehingga tidak menutup kemungkinan bahwa pengikatan jaminan yang melalui SKMHT dilakukan beberapa kali atau dilakukan perpanjangan SKMHT, karena proses dari letter $\mathrm{C}$ untuk menjadi sertifikat Hak Milik diperlukan waktu yang reletif cukup panjang yaitu kurang lebih 12 (dua belas) bulan.Jadi selama proses sertifikasi debitur menandatangi SKMHT dengan jangka waktu yang berlaku sampai 3 (tiga) bulan,sebagai mana yang diatur dalam Pasal 3 Peraturan Menteri Agraria dan Tata Ruang/Kepala Badan Pertanahan Nasional Republik Indonesia Nomor 22 Tahun 2017, tentang Penetapan Batas Waktu Penggunaan SKMHT.

Apabila jangka waktu SKMHT, telah berakhir dan berpanjangan SKMHT belum dilakukan, maka menjadi batal demi hukum, sebagai mana yang diatur dalam pasal 15 ayat (6) Undang-Undang Nomor 4 Tahun 1996 disebutkan SKMHT yang tidak diikuti dengan pembuatan akta pemberian hak tanggungan dalam jangka waktu sebagaimana yang dimaksud pada ayat (3) atau ayat (4), atau waktu yang ditentukan menurut ketentuan sebagaimana yang dimaksud pada ayat (5) batal demi hukum. 
Batal demi hukum adalah istilah hukum yang berarti bahwa dari awal tidak pernah ada suatu perjanjian atau perikatan. Dalam hukum Indonesia suatu perjanjian akan dianggap batal demi hukum jika tidak memenuhi syarat obyektif, yaitu suatu hal tertentu dan suatu sebeb yang halal, sebagaimana yang disebutkan dalamPasal 1320 Kitab UndangUndang Hukum Perdata (KUH Perdata), disebutkan bahwa untuk sahnya suatu perjanjian diperlukan empat syarat :

1. Adanya sepakat diantara mereka yang mengikatkan diri;

2. Adanya kecakapan untuk membuat suatu perikatan ;

3. Suatu hal tertentu ;

4. Suatu sebab yang halal.

Di dalam hukum perjanjian dikenal adanya asas kebebasan berkontrak, yaitu seseorang boleh memperjanjikan apa saja, asal tidak bertentangan dengan hukum yang bersifat memaksa, ketertiban umum, kesusilaan. dan kepatutan. Begitu juga dengan SKMHT yang memiliki batasan jangka waktu, sehingga apabila sampai dengan batas jangka waktu yang ditentukan SKMHT tersebut tidak dijalankan dianggap bahwa SKMHT tersebut dianggap tidak pernah ada. Hal tersebut selaras dengan asas kepastian hukum (pacta sun servanda), yaitu asas yang mengutamakan landasan peraturan perundang-undangan, kepatutan dan keadilan dalam setiap kebijakan penyelenggara negara.

Dalam Pasal 1335 KUH Pdt disebutkan bahwa perjanjian yang dibuat tanpa sebab atau dibuat dengan sebab yang palsu atau terlarang akan dianggap tidak mempunyai kekuatan. Begitu pula dalam Pasal 15 ayat (2) Undang Undang Nomor 4 Tahun 1996 disebutkan bahwa kuasa untuk membebankan hak tanggungan tidak dapat ditarik kembali atau tidak dapat berakhir oleh sebab apapun juga kecuali karena kuasa tersebut telah dilaksanakan atau karena telah habis jangka waktunya sebagaimana dimaksud pada ayat (3) dan ayat (4). Dengan demikian bilamana SKMHT jangka waktunya telah berakhir, dan tidak dilakukan penandatanganatau perpanjangan SKMHT, maka dianggap tidak pernah ada perjanjian, dan batal demi hukum.

\section{Upaya Hukum}

SKMHT memiliki batasan jangka waktu, hal ini diatur dalam Pasal 15 ayat (3) dan ayat (4) Undan-Undang Nomor 4 Tahun 1996 mewajibkan SKMHT diikuti dengan pembuatan APHT sesuai dengan batas jangka waktunya. Dalam Pasal 15 ayat (3) Undang-Undang Nomor 4 Tahun 1996, bahwa SKMHT mengenai hak atas yang sudah terdaftar, pada prinsipnya wajib untuk diikuti dengan pembuatan APHT selambat-lambatnya 1 (satu) bulan setelah ditandatangani SKMHT. 
Sementara itu, terhadap hak atas tanah yang belum terdaftar, termasuk tanah yang sudah bersertifikat, tetapi belum didaftar atas nama pemberi Hak Tanggungan sebagai pemegang hak atas yang baru, yaitu karena peralihan hak, pemecahan, atau penggabungan, kewajiban untuk pembuatan APHT-nya dilakukan selambat 3 (tiga) bulan sesudah ditandatangani atau diberikan SKMHT yang bersangkutan sebagaimana ditentukan dalam pasal 15 ayat 4 Undang-Undang Nomor 4 Tahun 1996.

Terhadap kredit tertentu, terutama kredit yang diberikan kepada golongan ekonomi lemáh dalam rangka kredit program pemerintah, dapat dikecualikan dari batas jangka waktu penggunaan sebagaimana ditentukan dalan pasal 15 ayat 5 Undang-Undang Nomor 4 Tahun 1996 yang berbunyi Ketentuan sebagaimana dimaksud pada ayat (3) dan ayat (4) tidak berlaku dalam hal surat kuasa membebankan hak tanggungan diberikan untuk menjamin kredit tertentuyang ditetapkan dalam peraturan perundangundangan yang berlaku.

Apabila dalam batas jangka waktu yang ditentukan, SKMHT dimaksud tidak diikuti dengan pelaksanaan pembuatan APHT, sesuai dengan ketentuan dalam pasal 15 ayat 6 Undang-Undang Nomor 4 Tahun 1996, maka SKMHT-nya batal demi hukum. Dinyatakan antara lain dalam penjelasan atas Pasal 15 ayat 6 Undang -Undang Nomor 4 Tahun 1996, bahwa ketentuan mengenai batas waktu berlakunya SKMHT dimaksudkan untuk mencegah berlarut-larutnya waktu pelaksanaan kuasa itu.

SKMHT pada umumnya dipergunakan dalam perjanjian kredit. Proses penggunaan SKMHT dalam perjanjian kredit secara umum samadengan perjanjian yang menimbulkan hutang piutang yang menggunakan SKMHT sebagai jaminan pelunasan hutang, sehingga para pihak kreditor dan debitor terlebih dahulu melakukan kesepakatan tentang apa yang akan dirumuskan dalam perjanjian kredit. Kesepakatan merupakan salah satu syarat sahnya suatu kontrak.

Setelah adanya perjanjian kredit sebagai perjanjian pokokyang memuat kesepakatan-kesepakatan para pihak tentang utang piutang selanjutnya dilakukan memasang hak tanggungan, terhadap satu atau lebih hak atas tanah dalam satu SKMHT yang bentuk dan isinya telah ditentukan oleh Peraturan Menteri Negara Agraria/Kepala BPN No. 3 Tahun 1996 yang membahas atau mengatur tentang SKMHT, APHT, Buku tanah hak tanggungan, dan sertifikat hak tanggungan.

Di dalam SKMHT dinyatakan bahwa untuk menjamin pelunasan hutang debitor maka pihak pertama diberikan dengan akta ini kepada dan untuk kepentingan pihak kedua, yaitu dengan ini menyatakan menerima hak tanggungan yang diatur dalam UUHT dan Paraturan Pelaksanaannya atas objek atau objek-objek Hak Tanggungan. 
Sebelum dilakukan penandatangan baik perjanjian kredit dan pengikatan jaminan melalui SKMHT, terlebih dahulu dilakukan pengecekan secara informal terhadap sertifikat yang menjadi jaminan tersebut, dalam hal pengecekan tersebut ditemukan sertifikat tanah yang akan dijadikan hak tanggungan tersebut bermasalah Notaris/PPAT harus menunda untuk membuat SKMHT sampai sertifikat tersebut dalam keadaan bersih dan bebas dari blokir ataupun proses pengadilan.

Setelah SKMHT ditandatangani, maka Notaris/PPAT harus melakukan pengecekan secara fisik keberadaan hak atas tanah yang akan dijadikan objek hak tanggungan atas permintaan pemberi hak tanggugan. Hal ini dilakukan Notaris/PPAT dengan membuat surat permohonan kepada pihak BPN Seksi Pendaftaran Tanah untuk memberikan informasi tentang keberadaan tanah yang akan dijadikan objek hak tanggungan, apakah hak atas tanah tersebut bebas dari sengketa dan apakah hak atas tanah tersebut sedang dibebankan hak atas tanah lainnya dan pada peringkat berapa hak tanggungan yang terakhir di atas hak atas tanah yang akan dijadikan objek hak tanggungan tersebut

Jangka Waktu yang ditentukan UU relatif terlalu singkat yaitu 1 (satu) bulan untuk tanah yang terdaftar dan 3 (tiga) bulan untuk tanah yang belum terdaftar. Waktu yang diberikan UU tersebut harusnya dipergunakan oleh Notaris /PPAT untuk memaksimalkan dan SKMHT tersebut jangka waktunya berakhir, syarat-syarat untuk dilakukan pemasangan hak tanggungan melalui APHT harus telah terpenuhi, antara lain telah pengecekan secara fisik terhadap sertifikat tersebut telah dilakukan, dengan hasil pengecekan sertifikat tersebut dalam keadaan bersih dan bebas dari blokir ataupun proses pengadilan ataupun proses balik nama sertifikat atas nama Pemberi Hak Tanggungan telah selesai.

Lamanya proses pembuatan SKMHT menjadi APHT di Kantor Notaris/PPAT, dikarenakan proses administrasi yang dilakukan Notaris/PPAT. Notaris/PPAT dengan waktu yang ditentukan oleh UndangUndang yang singkat harus melakukan pembuatan SKMHT menjadi APHT dengan cepat.

Lamanya proses pendaftaran hak tanggungan yang dilakukan pada Kantor Pertanahan, karena proses administrasi di Kantor Pertanahan dimana Buku Tanah Sertifikat belum diketemukan. Sedangkan SKMHT telah dibuat oleh Notaris /Pejabat Pembuat Akta Tanah (PPAT) sehingga SKMHT habis jangka waktunya, sedangkan pembuatan APHT belum dilakukan.

Hambatan pada pembuatan SKMHT khususnya oleh Notaris/PPAT yang membuat SKMHT tersebut secara yuridis tidak ditemukan. Hal ini dikarenakan pengaturan mengenai SKMHT telah jelas diatur dalam Undang-Undang HakTanggungan, akan tetapi hambatan tersebut ditemukan 
pada pengurusan secara administratif yaitu pada proses penggunaan SKMHT menjadi APHT.

Biaya menjadi salah satu hambatan peningkatan SKMHT menjadi APHT. Hal itu bukan karena biaya peningkatan SKMHT menjadi APHT oleh Pejabat Pembuat Akta Tanah (PPAT), namun karena proses selanjutnya yaitu pensertifikatan terhadap objek yang belum terdaftar tersebut memerlukan biaya yang mahal.

Lamanya proses pembuatan SKMHT menjadi APHT di Kantor Notaris/PPAT. Faktor yang menyebabkan lamanya proses pembuatan SKMHT menjadi APHT dikarenakan proses administrasi yang dilakukan Notaris/PPAT. Dengan waktu yang ditentukan oleh Undang -Undang yang singkat Notaris/PPAT harus melakukan pembuatan SKMHT menjadi APHT dengan cepat.

Lamanya proses pendaftaran hak tanggungan yang dilakukan pada Kantor Pertanahan. Penyebab lamannya proses pendaftaran hak tanggungan di Kantor Pertanahan karena proses administrasi di Kantor Pertanahan dimana Buku Tanah Sertifikat belum ditemukan, sedangkan SKMHT telah dibuat oleh Notaris atau PPAT, sehingga SKMHT habis jangka waktunya untuk pembuatan APHT.

Dalam praktek terhadap tanah yang belum terdaftar, setelah SKMHT ditandatangani maka proses yang sering menjadi hambatan adalah pensertifikatan membutuhkan waktu yang relatif cukup lama kurang lebih 12 (dua belas) bulan, sehingga memerlukan penandatangan SKMHT beberapa kali dan proses tersebut memerlukan biaya yang relatif cukup besar.

Seperti yang sudah dijelaskan diawal pembahasan bahwa PT. Bank Panin Tbk. Kabtor Cabang Blitar merupakan salah satu diantara kantor cabang PT. Bank Panin Tbk. yang memberikan fasilitas kredit untuk pelaku usaha UMKM (Usaha Mikro Kecil dan Menengah) baik untuk debitor perorangan maupun badan yang sebagian besar bergerak dalam bidang usaha pertanian, peternakan, perikanan dan industri kecil, dengan plafon kredit yang diberikan tidak hanya untuk fasilitas kredit dengan plafond di atas Rp. 50.000.000,- (lima puluh juta rupiah), tetapi juga pemberikan fasilitas kredit di bawah Rp. 50.000.000,- (lima puluh juta) Disamping itu PT. Bank Panin Tbk. Kantor Cabang Blitar ini, menerima jaminan kredit selain untuk tanah-tanah yang sudah bersertifikat juga menerima untuk tanah-tanah yang bukti kepemilikannya masih berupa letter $\mathrm{C}$ walupun selanjunya untuk kemudian diproses menjadi sertifikat.

Kondisi yang demikian tentunya relatif cukup banyak jaminanjaminan yang pengikatannya melalui SKMHT. Baik itu pengikatan jaminannya hanya cukup dengan penandatangan SKMHT karena fasilitas 
kredit yang diberikan kepada debitor dengan plafon kredit di bawah Rp. 50.000.000,- (lima puluh juta rupiah), sehingga jangka waktu SKMHT berlaku sampai dengan jangka waktu kredit. Diantaranya ada yang pembayaran angsurannya tidak lancar, bahkan tergolong kredit macet, sehingga untuk debitor yang pengikatan jaminannya hanya dengan SKMHT, bilamana ada keterlambatan dalam pembayaran angsuran atau sampai kredit tersebut tergolong macet, maka upaya yang dilakukan oleh PT. Bank Panin Tbk. akan melakukan pendekatan, semaksimal mungkin agar kredit tersebut bisa terselesaikan. ${ }^{6}$

Penandatanganan SKMHT sebagai solusi untuk proses penandatanganan APHT apabila persyaratan untuk dilakukan pemasangan APHT belum terpenuhi. Bilamana syarat untuk dapat dilakukan pemasangan hak tanggungan, sebaiknya segera dilakukan penandatangan APHT, berapapun fasilitas kredit yang diterima debitor hal ini dilakukan untuk melindungi kreditor. ${ }^{7}$

Dengan demikian tidak menutup kemungkinan dalam proses untuk dilakukan pemasangan APHT, mengalami hambatan yang dikarenakan debitor tidak bersedia memenuhi syarat-syarat yang telah disepakati bersama antara debitor dengan PT. Bank Panin Tbk., yaitu antara lain debitur tidak bersedia membayar biaya untuk pemasangan hak tanggugan, dan biaya untuk pemasangan hak tanggungan belum dicadangkan dari awal, sehingga PT. Bank Panin Tbk, tidak dapat melakukan pemasangan hak tanggungan, walaupun sudah ada keterlambatan pembayaran angsuran oleh debitor atau sudah ada tanda-tanda kredit macet, sehingga tidak dapat dilakukan proses pendaftaran hak tanggungan pada BPN dan penerbitan Sertifikat Hak Tanggungan (SHT) oleh BPN.

Kendala lain yaitu debitor tidak bersedia menandatangani perpanjangan SKMHT, karena salah satu penyebab debitor tidak memenuhi persyaratan karena kondisi usaha debitor mengalami penurunan. Padahal untuk tanah-tanah yang dalam proses sertifikasi memerlukan beberapa kali perpanjangan SKMHT, sampai diterbitkannya sertifikat. Bilamana debitor tidak menandatangi perpanjangan SKMHT ataupun APHT pada saat sertifikat (sertifikat Hak Milik) telah terbit, maka PT. Bank Panin Tbk. tidak dapat melakukan proses pendaftaran hak tanggugan pada BPN.

Bila terjadi hal yang dimikian atau terjadi kredit macet dan PT. Bank Panin Tbk. tidak dapat melakukan eksekusi terhadap agunan atau barang jaminan, karena pengikatan jaminannya hanya sebatas penandatangan

${ }^{6}$ Wawancara dengan Adhy Tsubut Habiburrohman, Authorized Signer PT. Bank Panin Tbk. Kantor Cabang Blitar, pada tanggal 23 Desember 2018.

${ }^{7}$ Wawancara dengan bapak Anang Susapto, Notaris/PPAT Kota Blitar dan Samsul Echwani, Notaris/PPAT Kabupaten Blitar. 
SKMHT, maka PT. Bank Panin Tbk. akan mengupayakan semaksimal mungkin untuk mencari jalan atau solusi agar kredit bermasalah bisa terselsaikan, yaitu denganmelalui pendekatan kepada debitor, untuk supaya debitor melakukan tindakan sebagai berikut: ${ }^{8}$

1. Mengupayakan agar debitor melakukan pembayaran biaya pemasangan hak tanggungan, yang dari awal belum pernah dicadangkan, dengan demikian dapat dilakukan pemasangan hak tanggungan, berikut pendanfatarn hak tangungan, pada BPN dan diterbitkan Sertifikat Hak Tanggungan (SHT), sehingga sewaktu-waktu PT. Bank Panin Tbk. dapat dilakukan penjualan dimuka umum melalui lelang ;

2. Memaksa debitor untuk menandatangani perpanjangan SKMHT, sampai proses sertifikasi selesai, dengan demikian setelah sertifikat (sertifikat Hak Milik) terbit, PT. Bank Panin Tbk, berdasarkan SKMHT melakukan pemasangan Hak Tanggungan, berikut pendaftaran hak tanggungan pada BPN dan diterbitkan Sertifikat Hak Tanggungan (SHT), sehingga sewaktu-waktu PT. Bank Panin Tbk. dapat dilakukan penjualan dimuka umum melalui lelang ;

3. Memaksa debitor untuk menandatangani APHT, bilamana sertifikat telah terbit, dan perpanjangan Surat SKMHT belum ditandangani, sehingga pada saat sertifikat telah terbit, debitor langsung menandatangi APHT, yang kemuadian dilakukan pemasangan hak tanggungan, berikut pendaftaran Hak Tanggungan pada BPN dan diterbitkan Sertifikat Hak Tanggungan (SHT), sehingga sewaktu-waktu PT. Bank Panin Tbk. dapat dilakukan penjualan dimuka umum melalui lelang;

4. Memberikan teguran atau somasi pertama, somasi kedua, somasi ketiga, baik secara intern dilakukan sendiri oleh PT. Bank Panin Tbk. maupun maupun melalui pengadilan;

5. Melakukan pelunasan baik sebagian maupun seluruhnya, untuk mengurangi kewajiban besarnya angsuran kredit ;

6. Mencarikan buyer, menghubungkan antara debitor atau pemilik jaminan dengan buyer, agar kredit macet bisa terselesaikan atau dilunasi;

7. Menandatangani akta kesepakatan bersama, yang pada intinya debitor menyerahkan dengan sukarela atas benda yangmenjadi jaminan.

\section{KESIMPULAN}

Akibat hukum bagi kreditor apabila SKMHT tidak diikuti dengan APHT. Berdasarkan analisa penulis atas pemberian kredit yang terjadi di PT. Bank Panin Tbk., Kantor Cabang Blitar, berkaitan dengan rumusan masalah diatas, dapat disimpulkan bahwa dalam pemberian fasilitas kredit

\footnotetext{
${ }^{8}$ Wawancara dengan Andri Pamungkas, Superveser Collections PT.Bank Panin Tbk. Kantor Cabang Blitar, pada tanggal 23 Desember 2018
} 
kepada debitor, PT. Bank Panin Tbk. Kantor Cabang Blitar disamping plafon kredit di atas Rp. 50.000.000,- (lima puluh juta rupiah) juga memberikan fasilitas kredit dengan plafon di bawah Rp. 51.000.000,- (lima puluh juta rupiah), sehingga untuk pengikatan jaminannya hanya melalui penandatangan SKMHT dan jangka waktu yang diberikan untuk SKMHT sampai berakhirnya perjanjian pokok. Hal ini dilakukan dalam rangka pemenuhan Pasal 2 Peraturan Menteri Agraria dan Tata Ruang/Kepala Badan Pertanahan Nasional Republik Indonesia Nomor 22 Tahun 2017, yang peraturan tersebut sebagai pengganti dari Peraturan Menteri Negara Agraria/Kepala Badan Pertanahan Nasional Nomor 4 Tahun 1996 tentang Penetapan Batas Waktu Penggunaan Surat Kuasa Membebankan Hak Tanggungan (SKMHT), namun perlu diingat bahwa SKMHT yang tidak diikuti dengan pembuatan APHT) maka batal demi hukum sebagaimana diatur dalam Pasal 15 ayat (6) Undang-Undang Nomor 4 Tahun 1996.

\section{DAFTAR PUSTAKA}

\section{Buku}

Boedi Harsono, 1999, Hukum Agraria Indonesia Jilit I, Jakarta: Djembatan.

Hadi Setia Tunggal., 2005, Undang-Undang Hak Atas Tanah Beserta Benda-Benda Yang Berkaitan Dengan Tanah Dan Perturan Pelaksanaanya, Jakarta: Harvarindo.

Rachmadi Usman, 2013, Hukum Kebendaan, Jakarta: Sinar Grafika. Supriadi, 2012, Hukum Agraria, Jakarta: Sinar Grafika.

Uswatun Hasanah, 2017, Hukum Perbankan, Malang: Setara Press.

\section{Peraturan Perundang-undangan}

Kitab Undang - Undang hukum Perdata.

Peraturan Menteri Negara Agraria dan Tata Ruang /Kepala Badan Pertanahan Nasional Republik Indonesia Nomor 22 Tahun 2017 tentang Penetapan Batas Waktu Penggunaan Surat kuasa Membebankan Hak Tanggungan (SKMHT) untuk Menjamin pelunasan Kredit-Kredit Tertantu.

Peraturan Menteri Agraria/Kepala Badan Pertanahan Nasional Nomor 3 tahun 1996 tentang Bentuk surat Kuasa membebankan Hak Tanggungan (SKMHT), buku Hak Tanggungan dan Sertifikat Hak Tanggungan.

Undang- Undang Dasar Republik Indonesia Tahun 1945.

Undang-Undang Nomor 5 Tahun1960 tentang Peraturan Dasar PokokPokok Agraria. 
Undang-Undang Nomor 4 Tahun 1996 tentang Hak Tanggungan Atas Tanah beserta Benda-benda yang berkaitan dengan Tanah.

Undang-Undang Nomor 7 Tahun 1992 jo. Undang-Undang Nomor 10 Tahun 1998 tentang Perbankan. 